\title{
Performance and Analysis of Unitized Stacked Load Units under Vibration Simulation
}

Bence Molnár

PhD Student

Széchenyi István University Department of Logistics and Forwarding

Hungary

Péter Böröcz

Associate Professor Széchenyi István University Department of Logistics and Forwarding Hungary

The unitized loads are the major form of the packed product transportation in logistics, and in most of the cases the packages are fixed to the pallet with straps, stretch film or these combinations to avoid the possible damages of products inside. During transportation various physical events such as vibration affect the product-packaging system. The nature of this vibration between the layers of stacked unit is not fully researched and understood. This paper focuses on the different motion of the layers in the unitized load in the function of the fixing modes using laboratory vibration simulations. Therefore, multiple unitized loads were built from the same quality corrugated paper boxes in three layers with various fixing modes to measure each layer motion separately. To carry out the simulation procedure, acceleration and vibration intensity on each layer was observed under sine and random vibration simulation. The recorded data shows, which layer motion is the most disparate from the excited motion, and which fixing variant causes this difference.

Keywords: stacked packaging, vibration simulation, distribution packaging, stacked vibration

\section{INTRODUCTION}

Vibration is one of the main hazards during the transportation [1]. This physical event can cause serious damages in the packaged-product system. The unitized load is the major form of a package-product system in distribution service [2], and they are usually built up from same packages in stack with different layout on distribution packaging device such as pallet. The most common fixing methods to stabilize the unit are the stretching and/or strapping the packages to pallet or to delivery vehicle. This paper focuses on the vibration differences between the layers of unitized load under various vibration simulation circumstances using different kinds of fixing method. The vibration simulation is one of the major forms to consider the adequacy of a packaging system. The simulations are usually based on testing standards that provide different vibration profiles such as ISO 13355 [3] (International Organization for Standardization), ASTM D4169 [4] (American Society for Testing and Materials), or ISTA series [5] (International Safe Transport Association). In these standards the vibration profiles simulate a time-compressed random signal to perform a similar vibration environment as transport vehicle platform has. Of course, there are some previous studies that focus on field measurement also and use vibration properties of a given distribution system. They measure the acceleration events with data recorder on the truck floor surface for various shipping

Received: May 2019, Accepted: September 2019

Correspondence to: Bence Molnár

Department of Logistic and Forwarding,

Egyeten tér 1., 9026 Győr, Hungary

E-mail: molnar.bence@sze.hu

doi:10.5937/fmet2001096M

(C) Faculty of Mechanical Engineering, Belgrade. All rights reserved routes, where the vibration depend on the type of the transport vehicle [6], its suspension [7], vehicle speed and the payload, and not least the quality of road [8], respectively. In the case of vibration analysis the power density (PD) levels are determined as a function of frequency based on the recorded random vibration acceleration levels as used other researches also $[9,10]$. The vibration environment is represented by the power density spectrum (PSD) showing a plot of the power density levels versus frequency. The energy within a specific frequency range can be obtained by integrating PSD within that frequency range (so called Overall $\mathrm{G}_{\mathrm{rms}}$ ). The computation of PSD is done directly using the method called Fourier transformation or computing autocorrelation function and then transforming it to use as diagnostic method $[11,12]$.

Some of the researchers investigated the behaviour of stacked packaging unit under vibration. The frequency response and the transmissibility characteristic of top-loaded corrugated paperboard containers were observed and the results of Godshall [13] identified the resonance of containers between 8.4 and $18.2 \mathrm{~Hz}$. Wang [14] investigated the behaviour of stacked corrugated paper boxes along sine and random vibration simulation. Fang et al. [15] investigated the statistical characteristics of maxima of contact force in stacked corrugated containers under random vibration.

But, the authors of this paper could not find any former paper that compared the vibration behaviour of unit load built up from corrugated packages along the different types of fixing methods. The aim of this paper is to identify the vibration response of layers in these unit loads and to determine the possible resonance frequency points of these systems by varied fixing methods. 


\section{METHODS}

\subsection{Measured unitized loads}

Two similar unit loads were set up for the measurement. Each of them contained twelve pieces corrugated paperboard boxes $(600 \times 400 \times 400 \mathrm{~mm})$ that were built up in three layers and four columns on EUR pallet $(800 \times 1200 \mathrm{~mm})$ to simulate a general package system. The weight of the boxes was $15 \mathrm{~kg}$, which value was calculated from the average shipment density showing in ASTM D4169. The filling material was PE (polyethylene) granulates in film bag, and EPS (expanded polystyrene) element secured the load at the bottom of the boxes with a width of $50 \mathrm{~mm}$. The samples for testing can be seen in (Figure 1). The size of the entire unitized load was $1200 \times 800 \times 1360 \mathrm{~mm}$, with a weight of $206 \mathrm{~kg}$.

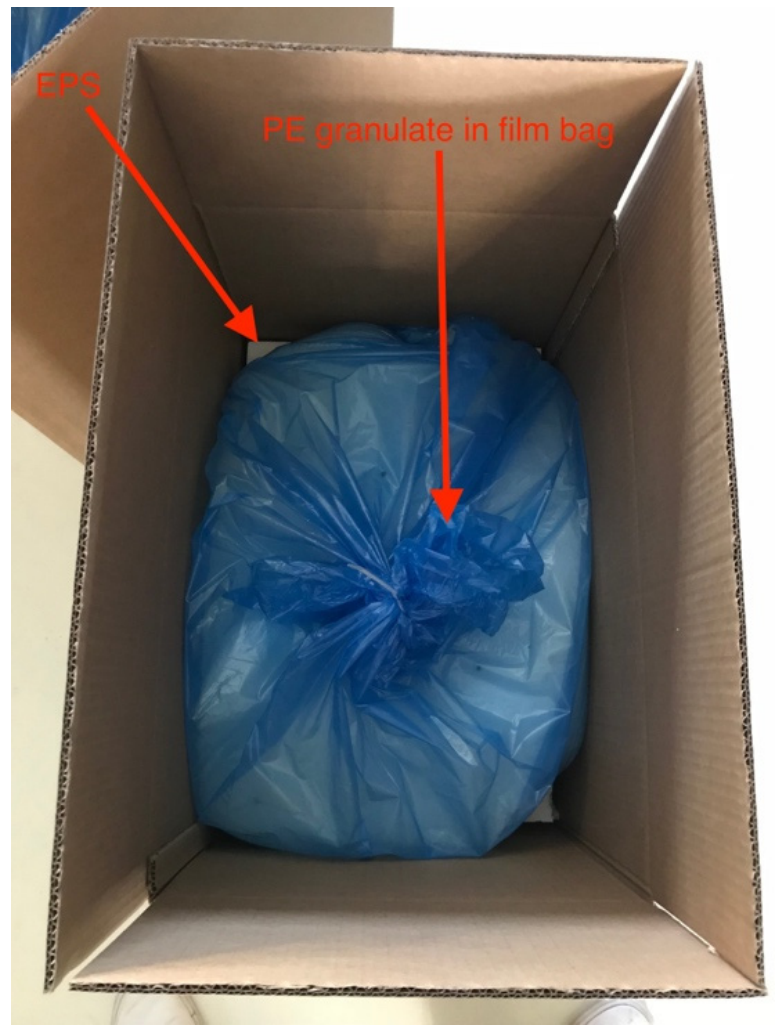

Figure 1. Sample box with filling material
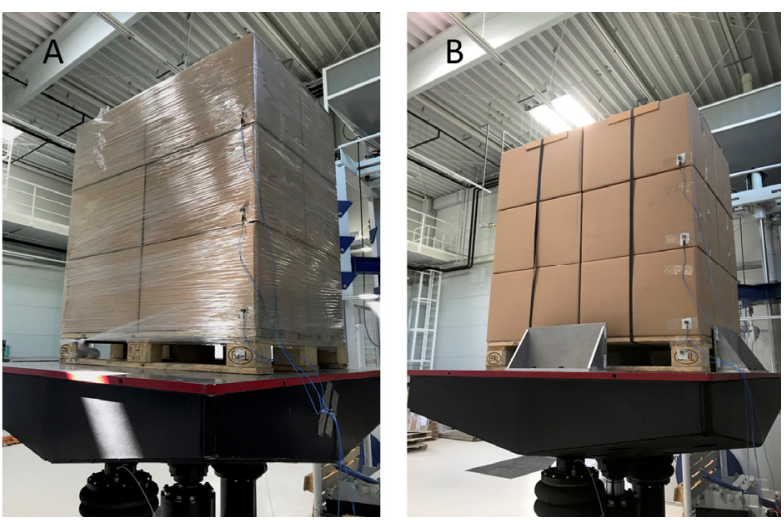

Figure 2. a) Stretch wrapped and b) strapped unitized loads on vibration table

The differences between the two unitized loads were only the fixing methods to the EUR pallet. The first one was fixed with stretch film, and the second one was fixed with plastic straps (Figure 2). For the stretching a hand polyethylene stretch film was used. The width of the stretch film was 500 millimetres and the thickness of the stretch film was 20 microns. Polypropylene strap tape was used for the strapping. The width of strap tape was $15 \mathrm{~mm}$ and with a thickness of $2 \mathrm{~mm}$. The straps were tensioned manually.

\subsection{Vibration system}

For the vibration simulation a hydraulic vibration table (LAB HV-60) was used with two VR Research 9500 vibration controllers. The table was controlled with two high sensitivity mono-axial accelerometers, and the response acceleration data were collected by four triaxial accelerometers. These accelerometers were fixed to the boxes' outer side, near the bottom corner with double-wall adhesive tape, and an additional accelerometer was fixed to the pallet. The accelerometers were located above each other (Figure 3). The data was recorded only in the vertical direction. The reason of this is this direction is the most intensive direction on the field due to the nature of citation by road roughness. All accelerometers collected the data by sampling frequency of $1634 \mathrm{~Hz}$, and FFT (Fast Fourier Transformation) type of Blackman window.

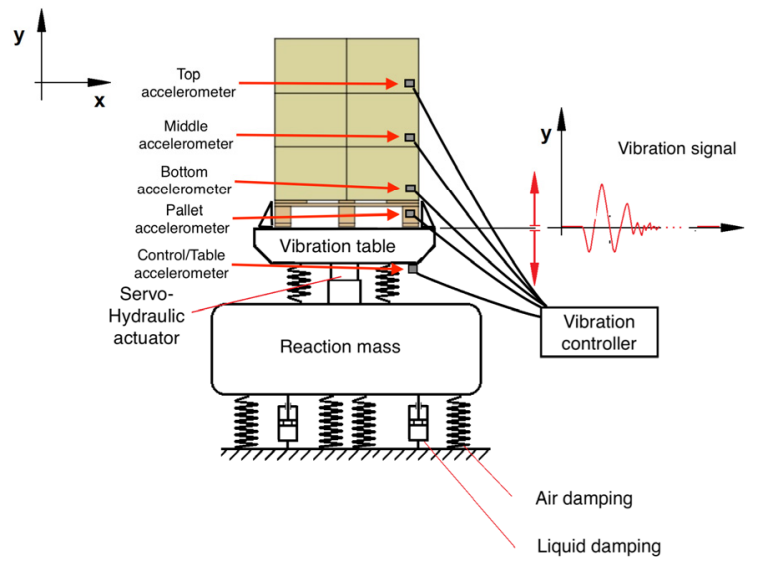

Figure 3: Position of the accelerometers

\subsection{Vibration profiles}

Sine sweep profile and two random (truck and air) vibration profiles were used for the observation of behaviour of units during the vibration. The whole frequency range was $2-200 \mathrm{~Hz}$. The amplitude was peak to peak 25 millimeters between 2 and $4.41 \mathrm{~Hz}$, and $1 \mathrm{G}$ between 4.41 and $200 \mathrm{~Hz}$ Between 2 and $4.41 \mathrm{~Hz}$, the servo-hydraulic vibration table cannot operate with $1 \mathrm{~g}$ amplitude, therefore the amplitude was 25 millimetres in this frequency range.

The random vibration simulations were performed according to ASTM D4169 truck profile Assurance Level II and ISTA 3A air vibration profile. The following table contains the breakpoint of random vibration profiles. (Table 1) Here have to be mentioned that the units were not fixed to the vibration table, only rigid fences were used to avoid the falling out. Finally, the acceleration data obtained vibration simulations were analysed with Matlab R2017a software. 
Table 1: Random profile breakpoints of truck and air vibration

\begin{tabular}{|l|l|l|l|}
\hline \multicolumn{2}{|l|}{ ASTM D4169 } & ISTA 3A & \\
\hline $\begin{array}{l}\text { Frequency } \\
(\mathrm{Hz})\end{array}$ & $\begin{array}{l}\text { PD Level } \\
\left(\mathrm{g}^{2} / \mathrm{Hz}\right)\end{array}$ & $\begin{array}{l}\text { Frequency } \\
(\mathrm{Hz})\end{array}$ & $\begin{array}{l}\text { PD Level } \\
\left(\mathrm{g}^{2} / \mathrm{Hz}\right)\end{array}$ \\
\hline 1 & 0.00072 & 2 & 0.00020 \\
\hline 3 & 0.01800 & 12 & 0.01000 \\
\hline 4 & 0.01800 & 100 & 0.01000 \\
\hline 6 & 0.00072 & 300 & 0.00001 \\
\hline 12 & 0.00072 & & \\
\hline 25 & 0.00360 & & \\
\hline 30 & 0.00360 & & \\
\hline 40 & 0.00072 & & \\
\hline 80 & 0.00360 & & \\
\hline 100 & 0.00360 & & \\
\hline 200 & 0.000012 & & \\
\hline $\begin{array}{l}\text { Overall } \\
\text { Grms }\end{array}$ & 0.542 & $\begin{array}{l}\text { Overall } \\
\text { Grms }\end{array}$ \\
\hline
\end{tabular}

\section{RESULTS AND DISCUSSION}

\subsection{Sine sweep}

Figure 4 and 5 show the measured accelerations of the various layers during sine sweep vibration. The result showed the acceleration values between $4-10 \mathrm{~Hz}$ on the middle and top layer were nearly twice as high as the excitation at stretch wrapped unit load. The bottom layer actually followed the excited acceleration of the vibration table. Above $10 \mathrm{~Hz}$ the acceleration levels that observed on the middle and top layers rapidly decreased. In the range of $100-180 \mathrm{~Hz}$ the acceleration levels on pallet and the bottom layer reached $3.26 \mathrm{~g}$ and $6.12 \mathrm{~g}$ comparing to the $1 \mathrm{~g}$ inputs.

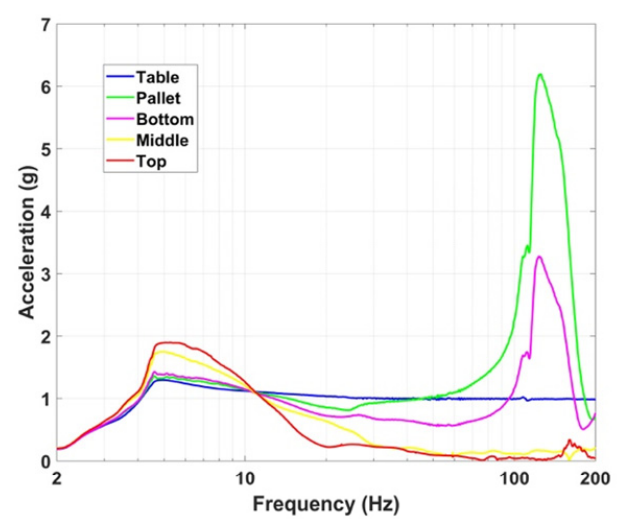

Figure 4: Acceleration levels of stretch wrapped unit load

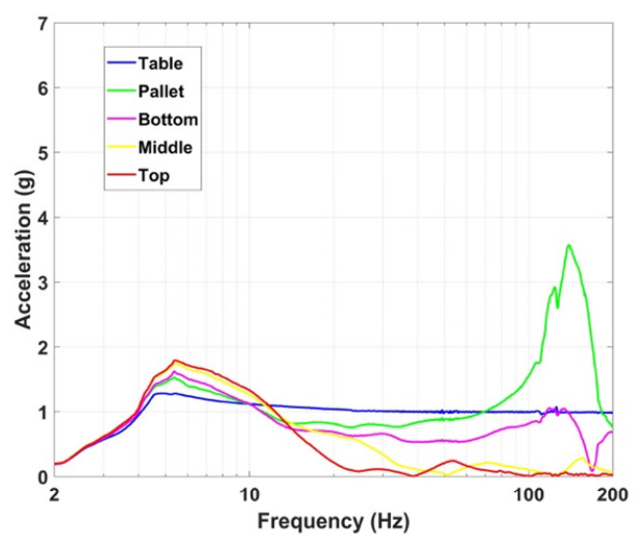

Figure 5: Acceleration levels of strapped unit load
In case of strapped version, in frequency range of 4 $10 \mathrm{~Hz}$, similar to the previous experiment each response acceleration levels exceeded the input and felt down below the input value over $10 \mathrm{~Hz}$, except the pallet response. The highest captures acceleration level was on the pallet with a value of $3.53 \mathrm{~g}$, at $139.6 \mathrm{~Hz}$.

\subsection{Random vibration}

The following figures (Figure 6 and 7) show the measured data during the ASTM random vibration profile. Similar to the sine vibration, the amplified PD (Power Density) levels were observed on the top and middle layers, in the range of $6-15 \mathrm{~Hz}$, and then over $100 \mathrm{~Hz}$ on the pallet and bottom layer. Here has to be noted that bottom layer of the strapped unit was the only one, which nearly followed the excitation during the entire frequency range.

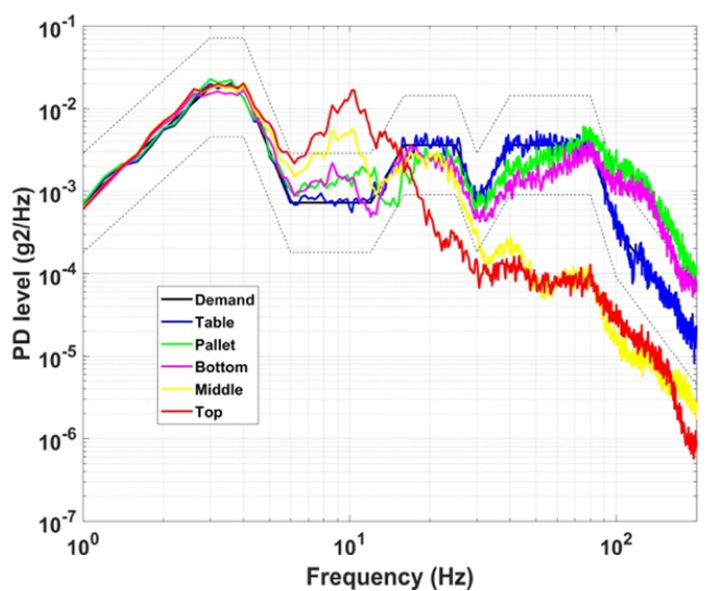

Fig. 6. PSD plot of stretched wrapped unit load

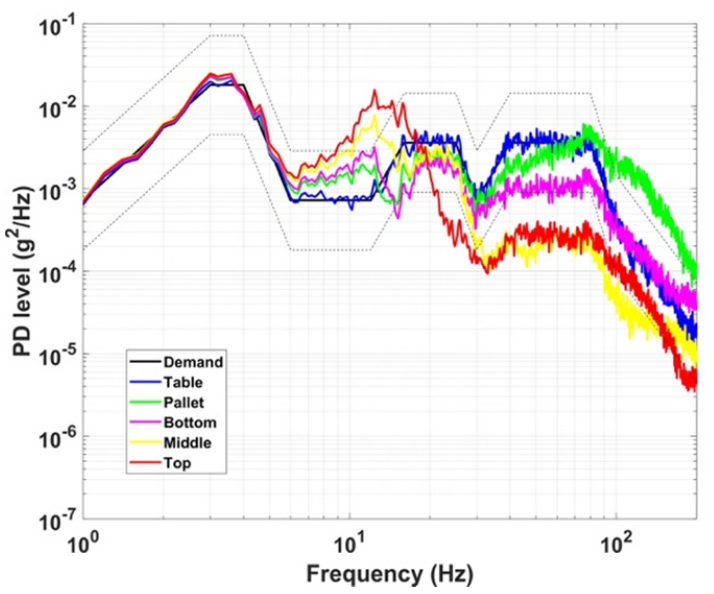

Figure 7: PSD plot of strapped unit load

Figures 8 and 9 show the differences of the two unitized load vibration responses in transmissibility plots. The peak of the transmissibility in case of the stretched unitized load's top layer was at $10.2 \mathrm{~Hz}$ and the transmissibility ratio was 24.91 . These values were $12.4 \mathrm{~Hz}$ and 12.54 for the strapped one. The middle layer's transmissibility values were around $8.83 \mathrm{~Hz}$ with a value of 6.83 . The pallet and the bottom layer cannot follow the motion of the table above $80 \mathrm{~Hz}$, the peak of the transmissibility was at $130.8 \mathrm{~Hz}$ with a ratio value of 38.44 for the wrapped unit load, and at $115.8 \mathrm{~Hz}$ with a ratio of 23 for strapped one. 


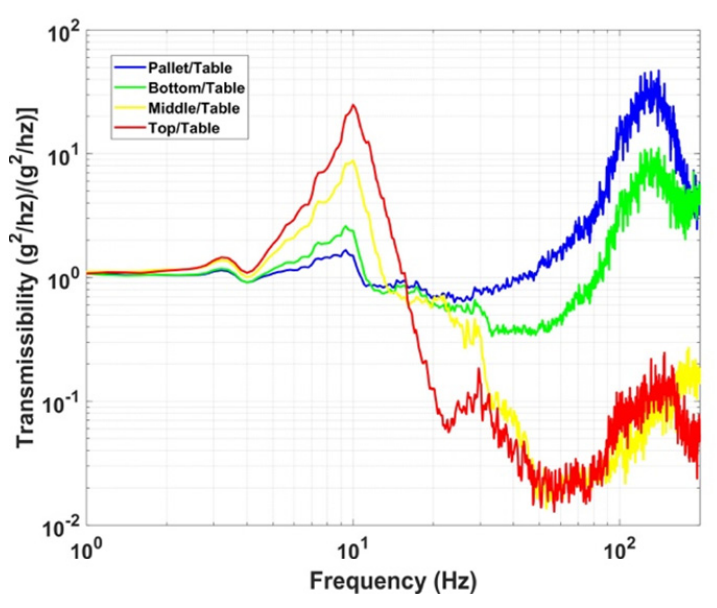

Figure 8: Transmissibility plot of stretch wrapped unit load

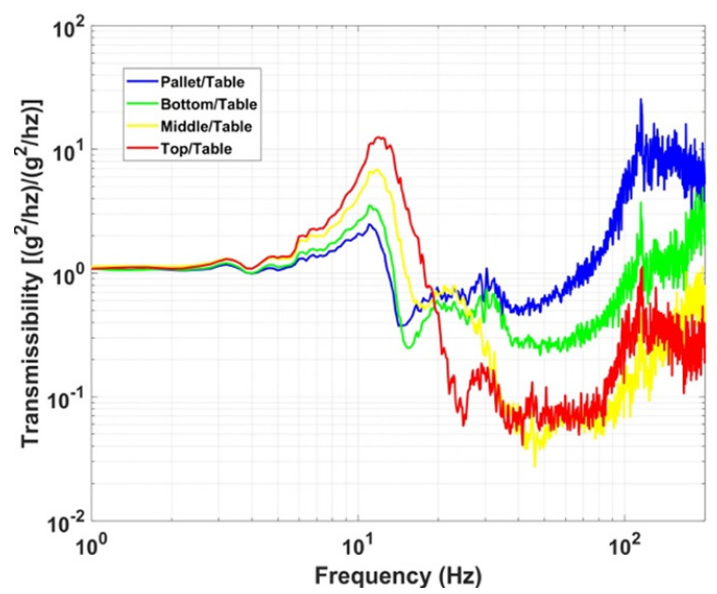

Figure 9: Transmissibility plot of strapped unit load

Finally, the unit loads were investigated under ISTA 3A Air random vibration, and similarly like at truck vibration simulation, the PSD (Figure 10 and 11) and transmissibility (Figures 12 and 13) plots are presented for this study. Likewise, at the ASTM truck random simulation, the upper layer's motion differed from the motion of bottom and the pallet layers, which follow the excitation between 5-13 Hz. Similar to the ASTM and sine vibration simulation, the middle and top layers accelerations decreased over $13 \mathrm{~Hz}$. The behaviour of these layers above $130 \mathrm{~Hz}$ was different for the type of unit loads. In case of stretch wrapped unit, the measured PD levels of the bottom layer and the pallet significantly increased from $65 \mathrm{~Hz}$.

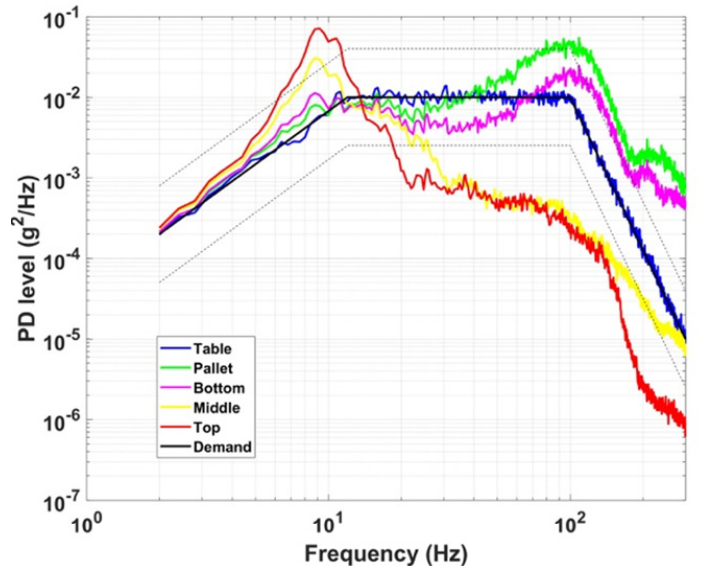

Figure 10: PSD plot of stretched wrapped unit load

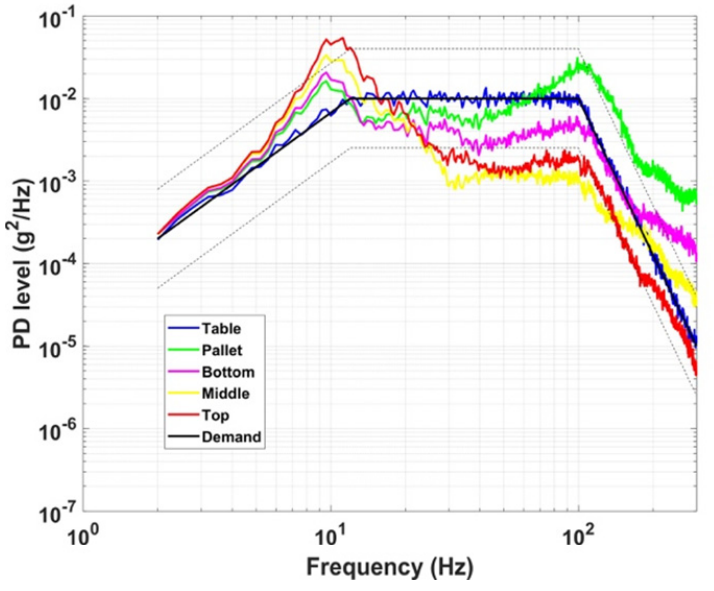

Figure 11: PSD plot of strapped unit load

The above-mentioned phenomenon can also be revealed by the following two figures (Figures 12 and 13), which illustrate the transmissibility ratio between the layers and the vibration table input. When comparing the two figures, the difference in the movement of the layers of the two variant is immediately visible. The peak of the transmissibility in case of the stretched unitized load's top layer was at $8.8 \mathrm{~Hz}$ and the transmissibility ratio was 13.28 , and these values were $10 \mathrm{~Hz}$ and 7.26 for the strapped one. The middle layer's transmissibility values were at this frequency point 5.8 and 4.53 . The pallet and the bottom layer cannot follow the motion of the table above $80 \mathrm{~Hz}$, from this frequency point the transmissibility ratio continuously increased.

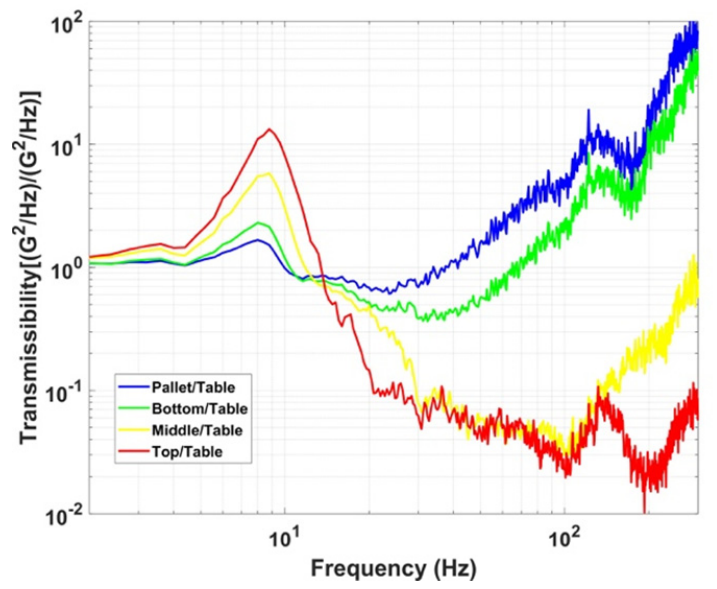

Figure 12: Transmissibility plot of stretch wrapped unit load

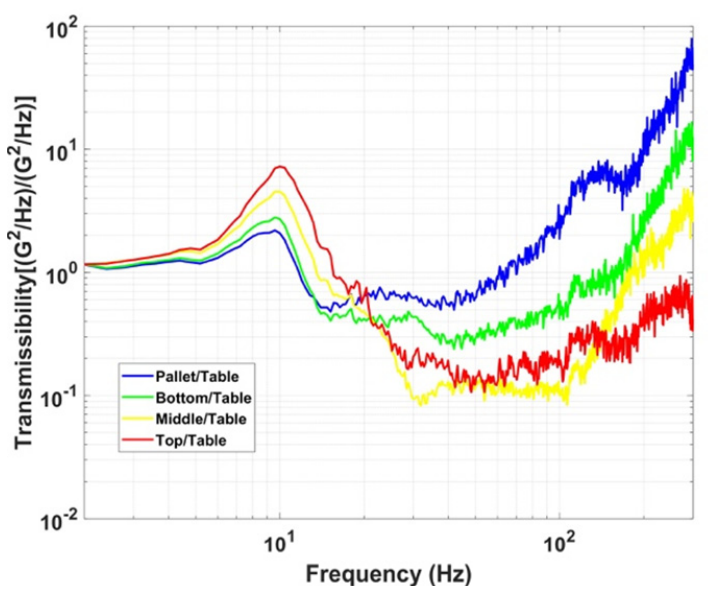

Figure 13: Transmissibility plot of stretch wrapped unit load 


\section{LIMITATIONS OF STUDY}

The authors of this paper want to call attention to the fact that the method of PSD involves the use of the Fast Fourier Transformation (FFT) process and due to this this it produces a PSD profile with average intensity of the vibration over the frequency range of interest [16]. Furthermore, the use of presented PD levels as vibration simulation conditions do not expose the test items to extreme levels of vibration or transients like shock events, which can occur during real transportation. Last, but not least it has to be recognized by the readers of this paper that the intensity of the test standards applies time-compression [17], which artificially amplifies the vibration magnitude comparing to the real life.

\section{CONCLUSION}

The results show that the top and middle layers' response acceleration values in unit loads are significantly higher than the excitation in the frequency range of $6-14 \mathrm{~Hz}$ during sine sweep simulation. In the higher frequency range (over $80 \mathrm{~Hz}$ ) the bottom layer attenuates these layers' motion. The significantly amplified PD levels could be found during the ASTM random vibration simulation, when the top and middle layers showed the a very high amplifying in the range of $6-15 \mathrm{~Hz}$, and over $100 \mathrm{~Hz}$ it could be experienced on the pallet and bottom layer only. From the results of this study the following conclusion can be drawn: the measured response acceleration values were higher at the stretch wrapped unit load than at the strapped sample. This may be due to the fact that strapping can prevent better the vertical movements than the stretch wrapping.

\section{ACKNOWLEDGMENT}

The research for this paper was financially supported by the EU and the Hungarian Government from the project. Intensification of the activities of HU-MATHS-IN Hungarian Service Network of Mathematics for Industry and Innovation" under grant number EFOP-3.6.216-2017-00015.

\section{REFERENCES}

[1] Fragassa, C., Macaluso, I., Vaccari, M., Lucisano, G.: Measuring the mechanical and climatic conditions encountered by palletized products in handling and transport. FME Transactions, Vol. 45, No. 3, pp. 382-393, 2017. doi:10.5937/fmet 1703382F

[2] Yam, KL.: Encyclopedia of Packaging Technology, John Wiley \& Sons Inc.: Hoboken, USA, 2009

[3] ISO 13355: Complete, filled transport packages and unit load - vertical random vibration test, International Organization for Standardization, 2003

[4] ASTMD4169-14, Standard practice for performance testing of shipping container systems. 2014. http://www.astm.org/[accessed 01 January 2016]

[5] ISTA Procedure 3A. Packaged-Products for Parcel Delivery System Shipments $70 \mathrm{~kg}(150 \mathrm{lb})$ or Less (Standard, Flat or Elongated). International Safe Transit Association: East Lansing, 2006.
[6] Böröcz, P, Singh SP: Measurement and analysis of delivery van vibration levels to simulate package testing for parcel delivery in Hungary. Packaging Technology and Science 2018; 31(5), pp. 342-352, DOI: $10.1002 /$ pts.2327

[7] Böröcz P. Vibration Levels in Vans as a Function of Payload and Leaf Spring, Sheet Number. Journal of Testing and Evaluation 2018; 46(1), pp. 236243, DOI: $10.1520 /$ jte20160538

[8] Pidl, R. Böröcz, P.: Discrete Fourier Transform and Cepstrum Analysis of Vibration Events on Semitrailer Truck, FME Transactions 2019, 47(1), pp. 177-182. DOI:10.5937/fmet1901177P

[9] Ilić, Z., Rašuo, B., Jovanović, M., Janković, D.: Impact of Changing Quality of Air/Fuel Mixture during Flight of a Piston Engine Aircraft with Respect to Vibration low Frequency Spectrum, FME Transactions, Vol. 41 No.1, pp. 25-32, 2013.

[10]Ilić, Z., Rašuo, B., Jovanović, M., Pekmezović, S., Bengin, A., Dinulović, M.: Potential Connections of Cockpit Floor - Seat on Passive Vibration Reduction at Piston Propelled Airplane, Technical Gazette, Vol.21, No.3, pp. 471-478, 2014.

[11] Matijević, D.V. et al.: Overview of Modern Contributions in Vehicle Noise and Vibration Refinement with Special Emphasis on Diagnostics, FME Transactions, Vol. 45, No. 3, pp. 448-458. 2017.

[12] Ilić, Z., Rašuo, B., Jovanović, M., Jovičić, S., Tomić, Lj., Janković, D., Petrašinović, D.: The Efficiency of Passive Vibration Damping on the Pilot Seat of Piston Propeller Aircraft, Measurement, Vol. 95, pp. 21-32, 2017.

[13] Godshall WD. Frequency response, damping and transmissibility characteristics of top-loaded corrugated containers, United States Department of Agriculture, Forest Service, Forest Products Laboratory, Research Paper FPL 160, 1971.

[14] Wang, Z.-W. et al.: Dynamic Performance of Stacked Packaging Units. Packaging. Technology and Science 2016; 29, pp. 491-511, DOI: 10. 1002 /pts.2232

[15] Fang K.Wang Z.-W. The Statistical Characteristics of Maxima of Contact Force in Stacked Packaging Units under Random Vibration. Packaging Technology and. Science 2018; 31, pp. 261-276, DOI:10 $.1002 /$ pts. 2313

[16]Böröcz, P. Averaged Vibration Levels During Courier Parcel Delivery Service in Small Truck in Hungary, FME Transaction 2018; 46 (2), pp. 211217. DOI:10.5937/fmet1802211B

[17] Shires D. On the time compression (test acceleration) of broadband random vibration tests. Packaging Technology and Science 2011; 24(2); pp. $75-87$. DOI: $10.1002 /$ pts.915

\footnotetext{
ПЕРФОРМАНСЕ И АНАЛИЗА НАСЛАГАНИХ ТОВАРНИХ ЈЕДИНИЦА СПОЈЕНИХ У ЈЕДНУ ЈЕДИНИЦУ У УСЛОВИМА СИМУЛАЦИЈЕ ВИБРАЦИЈА
} 


\section{Б. Молнар, П. Береч}

Спојене товарне јединице представљају главни проблем у логистици транспорта упаковане робе и у већини случајева пакети су фиксирани за палету помоћу каишева, еластичног филма или се користи њихова комбинација да би се избегло могуће оштећење робе унутар паковања. У току транспорта јављају се различите физичке појаве као што су вибрације које утичу на систем паковања. Природа вибрација између слојева спојених товарних јединица није до краја истражена. Овај рад се бави различитим кретањима слојева у спојеним товарним јединицама да би се онемогућило кретање ових слојева применом симулације вибрација. У циљу истраживања товарне јединице су израђене од кутија од таласастог картона и спојене у три слоја различитим средствима за фиксирање да би се мерио начин померања сваког слоја појединачно. Поступак симулације, интензитет убрзања и вибрација посматран је код сваког слоја уз симулацију синусних и случајних вибрација. Резултати показују који се слој највише разликује у погледу побуђеног кретања и која варијанта фиксирања највише утиче на ову разлику. 